\title{
Variation of Mathematical Representation Used in Students' Textbook Grade 8 Semester 2
}

\author{
$1^{\text {st }}$ Varetha Lisarani \\ Graduate School of State \\ University of Malang \\ Malang, Indonesia \\ me.at16@gmail.com
}

\author{
$2^{\text {nd }}$ I Nengah Parta \\ Mathematics Department \\ State University of Malang \\ Malang, Indonesia \\ nengah.parta.fmipa@um.ac.id
}

\author{
$3^{\text {rd }}$ Tjang Daniel Chandra \\ Mathematics Department \\ State University of Malang \\ Malang Indonesia \\ tjang.daniel.fmipa@um.ac.id
}

\begin{abstract}
Due to the abstract nature of mathematics, it is not possible to access mathematical objects without the use of representations. Representations can help to make mathematical ideas more concrete and available for reflection. Hence, they can help students to organize, record, and communicate their thinking. Representations refer to both product and process - that is, they work both internally and externally. Since we cannot observe internal representations directly, we make inference about them by their external representations. There are three forms of representation that are frequently encountered in mathematics textbooks namely written symbols, pictures, and real-world situations. The objective of this paper is to describe the variation/forms of the above representations that are used in Indonesian mathematics textbook for Grade 8, particularly in the probability unit. The results of the study indicate that in the probability unit, the realworld situation is the most frequently used form of representation, and written symbol is the least frequent.
\end{abstract}

Keywords-Mathematical representation, Probability unit, Textbook,

\section{INTRODUCTION}

Mathematical representation plays a vital role in scientific activities [1]. Duval in Friesen and Kuntze said that due to the abstract nature of mathematics, it is not possible to access mathematical objects without the use of representations [2]. All mathematical reasoning requires the use of representations [3]. In mathematics, we translate the realistic object into the object as the model, which the model is a representation from the essential aspects of a real object [4]. How mathematical ideas are represented is fundamental to how people can understand and use those ideas. Students' use of representations can help to make mathematical ideas more concrete and available for reflection. Therefore, it can help the students to organize, record, and communicate their thinking [5]. Due to its importance, the National Council of Teachers of Mathematics (NCTM) even included representation in their Process Standards; Problem Solving, Reasoning and Proof, Communication, Connection, and Representation.

Representation refers to both product and process, that is, it stands for the act of representing as a verb and also for the external form of the representation as a noun [5,6]. In the domain of mathematics, the representation can be viewed as abstractions of mathematical ideas or cognitive schemataalso thought as internal. On the other hand, the representation such as numerals, algebraic equations, tables, graphs, charts, and diagrams are external manifestations of mathematical concepts that help students understand the concepts [6]. As a process, verb, and intrinsic meaning, Goldin and Shteingold explained that it includes students' personal symbolization constructs and assignments of meaning to mathematical symbols, which can be divided into four different kinds: verbal/syntactic, imagistic, formal notational, and also strategic and heuristic representation [7]. Since these are cannot be observed directly, thus we make inference about students' internal representation by their interaction with, explanation about, or production of external representations. Representation as product, noun, and external meaning is a model or a substitute for a problem situation that used to find a solution which is mainly notational and formal $[7,8]$. Goldin explained that representation includes configuration of signs, characters, icons, or objects that can somehow stand for or represent something, which includes conventional graphical, diagrammatic, and formal notational system of mathematics, also concrete manipulative materials or computer-based micro worlds [9]. Words and sentences both written and spoken are also external representation [7].

Representations are an essential part of learning and doing mathematics since the ways mathematical ideas are represented as fundamental to how students can understand and use them $[5,10]$. Representation is also related to students' ability in communication and problem solving [8]. The use of representations allows teachers to explain mathematical concepts in ways that are more accessible to students [10]. Teachers also may gain valuable insights into students' ways of interpreting and thinking by looking at their representations [5]. Students' construction of knowledge is closely related to the external representation of the knowledge, and a good problem solver tends to be flexible in using a variety of relevant representations that he/she instinctively switches to the most convenient form $[11,12]$. Lack of support in reflecting and making connections between different representations can lead to difficulties in students' understanding [2]. As explained by Lesh, Landau, and Hamilton, there are five different forms of mathematical representation: 1) manipulative media, 2) written symbols, 3) spoken symbols, 4) pictures (static figural model), and 5) real-world situations [13].

Lesh, Post, and Behr then further explained the representation forms [12]: 1) Models such as arithmetic blocks, fraction bars, and number lines, in which each has little meaning, but the build in relationships and operations fit many everyday situations; 2) Written symbols which may involve specialized sentences and phrases, such as $x+3=7$, as well as normal ones; 3) Spoken symbols or spoken languages, also including specialized sub-languages related to disciplines; 4) Pictures (static figural model) which can also be internalized as 'images'; and 5) Real world situations 
are experience-based 'scripts' where knowledge is organized according to 'real world' events, serving as general contexts in interpreting and solving other kinds of problem situations. Three of those five forms of representation (written symbols, pictures, and real-world situations) are mostly used in students' textbook.

A textbook is one of the significant learning resources for students. Hence, Sutherland explained that how students construct a mathematical idea, which could be influenced by the ways mathematics structured [18]. Therefore, attention should be paid to the textbooks, especially to the textbooks that are distributed by the government and commonly used by the majority of the students in a country, to assess whether they are suitably designed to support students on attaining a full range of mathematical abilities which in this case, the ability of representation [14]. Unfortunately, although mathematics textbooks provide a window onto the mathematics education world of a particular country, there is less of analytical research which has focused on how mathematics is presented in textbooks [11]. Therefore, this paper will describe the variation of representations used in mathematics textbook distributed by the Indonesian government for the $2^{\text {nd }}$ semester of the $8^{\text {th }}$ grader.

\section{METHODS}

This study is a descriptive-qualitative one which will describe the variety of mathematical representations used in the probability unit of Indonesian mathematics textbook for the $2^{\text {nd }}$ semester of $8^{\text {th }}$ grader, using forms of representation explained by Lesh, Post, and Behr [12]. For this study, there's no claim that the unit and textbook analyzed in some way represent all the units and textbooks which might be used in Indonesia.

\section{RESULTS}

The textbook being studied is the students' mathematics textbook which was published by Indonesian Ministry of Education and generally used in Indonesia. The probability unit in the textbook is divided into two subunits; 'Understanding Theoretical Probability' and 'Comparing Empirical and Theoretical Probability,' and then closed by 'Competence Test' at the very end of the unit. There are two basic competencies for this unit; 1) finding empirical and theoretical probability from possible output based on a group of data, and 2) experimenting to find empirical probability from real-world problems and comparing it with theoretical probability [16]. The result of the study will be explained based on the three forms of representation by Lesh, Post, and Behr which are found in textbooks: 1) real-world situations, 2) pictures, and 3) written symbols [12].

As suggested by the basic competencies, generally probability is closely related to real-world events; hence representation in real-world situation form is often encountered compared to other units in this book such as quadratic equation and circle unit. In the opening of the first subunit, authors of this book wrote real-world situations related to the soccer game and student organization. In the opening of the second subunit, the real-world situation such as die tossing is to compare empirical and theoretical probability. The using of the real-world situation in the opening of the subunits suggests that the author tried to connect the unit to the real-world situation; students will feel that the material being studied is closely related to their daily lives, resulting into students' curiosity and attention. Real world situations also encountered in the "Ayo Kita Amati" (observing), "Ayo Kita Menggali Informasi" (exploring), and "Ayo Kita Menalar" (associating) sections of both subunits. Each item in the Exercises section of both subunits (5 items in the first subunit and six items in the second subunit) and the Competence Test (15 items) is also related to real-world situations. This excessive use of real-world situation is linear to the basic competence of the probability unit, which expected to result in meaningful learning.

\section{Pertandingan Sepak Bola}

» Pada suatu pertandingan sepak bola antara Timnas Indonesia U-19 melawan Malaysia U-19 terjadi saling serang antar kedua tim. Meskipun begitu, hingga menit 90 belum ada satu pun gol tercipta, schingga skor masih 0 - 0 . Timnas Indonesia berpeluang memenangkan pertandingan ketika mendapatkan hadiah tendangan penalti pada saat menit perpanjangan. Tendangan tersebut diambil oleh Ilham, yang merasa siap untuk menendang penalti tersebut. Namun ternyata tendangan Ilham tidak membuah goal. Akhirnya skor akhir masih imbang tanpa gol antara Indonesia dan Malaysia. Setelah pertandingan tersebut banyak pendukung timnas Indonesia antar lain Made dan Boaz. Berikut percakapan antara Made dengan Boaz yang kecewa dengan hasil akhir tersebut.

Made : Saya yakin kalau Evan Dimas yang menendang tendangan penalti tersebut pasti goal. Bagaimana menurutmu Boaz?

Boaz: Iya, saya yakin peluang terjadinya goal besar kalau Evan Dimas yang menendang. Saya yakin $100 \%$ goal.

Made : Wah, bukan $100 \%$ aja Boaz, menurut saya malah $200 \%$ goal karena tendangannya hebat, dan Indonesia menang. 


\section{(TRANSLATION) Soccer Game}

In a soccer game between the national team of Indonesia U-19 versus Malaysia U-19, both teams were attacking each other. However, until 90 minutes passed on, there's no goal made, the score was still $0-0$. The Indonesian national team got an opportunity to win the game when they got penalty kick at the injury time. The kick was taken by Ilham, who was sure that he would get to score. However, unfortunately, his kicked a miss. The game then ended with no goal scored by both of Indonesia and Malaysia. After the game, supporters of the Indonesian national team are disappointed with the result; ones of them are Made and Boaz. Below is the conversation between them.

Made: I am sure if Evan Dimas kicked the penalty he would score a goal. How do you think about that, Boaz?

Boaz: I think that the success probability is significant if Evan Dimas is the one who kicked the penalty. I am sure the success probability is $100 \%$.

Made: Well, not only $100 \%$, I think it is undoubtedly $200 \%$ a goal since his kicks are excellent, and Indonesia will surely win

Fig. 1. Real World Situation of Soccer Game in Indonesian $8^{\text {th }}$ Grade Textbook

Since probability is closely related to real-world situations, it is also related to real-world objects, implying this unit uses relatively many pictorial illustrations. There are illustrations of coins (encountered twice), dice (encountered four times), spinners (encountered three times), and a menu list. Unfortunately, there's no other picture such as the illustrations of the soccer game or student organization's chairman of the opening of the first subunit. Other than pictorial illustrations, this unit also presents information in tables (encountered 12 times), arrow diagrams (encountered twice), and a graph.

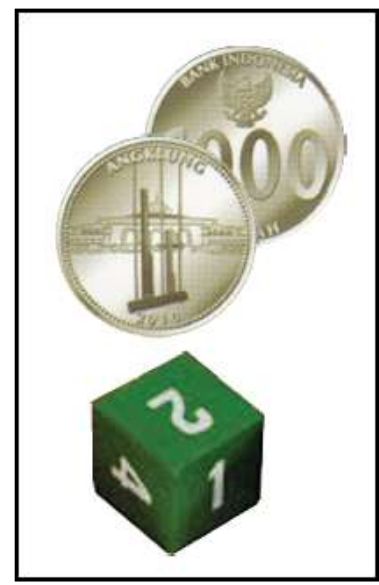

Fig. 2. Pictorial Illustrations of Coins and a Die in Indonesian $8^{\text {th }}$ Grade Textbook
The last form of representation found in this book is written symbols, which is only encountered three times as a formula of theoretical probability, empirical probability, and expected frequency, and also few times as symbols representing the face of a coin. Unfortunately, this book frequently uses $A$ and $G$ which are supposed to stand for "Angka" (number) and "Gambar" (head) of a coin, respectively, but did not explain what $A$ and $G$ stand for at the beginning of the unit. The explanation only presented by exploring the section of the first subunit, which is placed after the opening, observing, and questioning sections of the subunit. In general, this unit did not present many written symbols, as the symbols are frequently used in the solving process of probability problems.

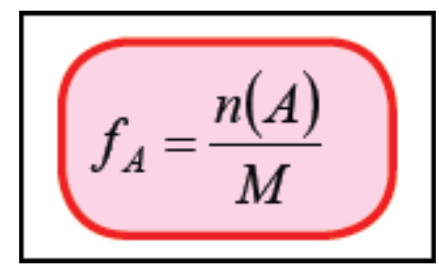

Fig. 3. Written Symbol of Empirical Probability in Indonesian $8^{\text {th }}$ Grade Textbook

\section{DISCUSSION}

Lesh, Post, and Behr explained that there are three indicators that a student 'understands' an idea: 1) the student can recognize the idea embedded in a variety of qualitatively different representations, 2) the student can flexibly manipulate the idea within given representations, and 3) the student can accurately translate the idea from one representation to another [12]. This explains the reason we found the variety of representations in the textbook being studied. The variation may help students who have difficulties in translating from real-world situations to written symbols; they may begin by translating from realworld situations to pictures and then translate from pictures to written symbols, and also vice versa.

Since the textbook being studied is written based on Indonesia's Curriculum 2013, here we will discuss the relationship between the result of this study and the curriculum itself. As stated in Curriculum 2013's Process Standard, students are seen as subjects who are capable of actively finding, processing, constructing, and using knowledge; hence the instruction must give students opportunities that allow them to construct knowledge in their cognitive process. Core competence 4 for $8^{\text {th }}$ grade students is "processing, presenting, and reasoning in concrete domain (using, explaining, connecting, modifying, and making) and abstract domain (writing, reading, calculating, drawing, and composing) based on what learned in the school and based on another sources which equal in point of view/theory" [15]. For the probability unit, there are two necessary 
competencies; 1) finding empirical and theoretical probability from possible output based on a group of data, and 2) experimenting to find empirical probability from real-world problems and comparing it with theoretical probability [16]. In the textbook being studied, a real-world situation is the most common form of representation found. This form of representation will allow students to relate the material to their surrounding; hence it will help them in constructing knowledge, as suggested in Curriculum 2013 's Process Standard. The excessive use of the realworld situation is also related to the nature of probability that is inseparable from real-world events, which is also illustrated in the basic competencies. All three forms of representation found in this book are also instrumental for students in achieving the $4^{\text {th }}$ core competence (processing, presenting, and reasoning on concrete and abstract domain); students are familiarized in working on the probability in the real world situations, then pictures will help them in abstracting the concept, which one form is a written symbol.

Relating the result of the study to Piaget's theory, the real-world situation is also suitable for the students' cognitive stage - since the average age of Indonesian $8^{\text {th }}$-grade students is 13-14 years old-they are included in formal operation stage. Piaget explained that earlier in this stage, students shift from the concrete operational stage to the formal operation stage [17]. Hence, students are still in need of contextual situations rather than abstraction, and realworld situations are proper assistance in facilitating the shifting. In the textbook, there are some activities which are based on real-world situations that demand students to do experiments such as determining sample space of tossing coins and dice and determining the empirical probability of choosing colored marbles randomly from a bag. The book also includes another form of representations such as the picture of dice and coins and written symbol of empirical and theoretical probability. Those representations will help students to shift from the concrete operational stage to the formal operation stage, as Piaget suggested. Also, since from the result of this study we see that majority of the representation in the textbook is in the form of realworld situations, this will make sure that students in the formal operation stage are given enough opportunities to fantasize the situation written in the textbook; hence they refrain from daydreaming [17].

If Piaget's theory emphasizes more on the student's stage of cognitive development, Bruner's theory emphasizes more on students' use of representation. According to Bruner, there are three levels of engagement with representations: inactive (e.g., manipulating concrete materials), iconic (e.g., pictures and graphs), and symbolic (e.g., numerals). Bruner also emphasized that children have to actively and independently work to discover the basic principles of a subject [6]. From our findings in the textbook, we see that three forms of representation in probability unit (real-world situation, picture, and written symbol) are in the level of iconic and symbolic representation of Bruner's theory. The inactive level is not visible in the textbook, but there are experiments suggested in the textbook (such as in "Ayo Kita Menggali Informasi" and "Ayo Kita Selidiki" sections) that allows students to manipulate concrete materials such as coins and dice. Here we can see that excessive appearing of real-world situations in the textbook will encourage students to be actively imagining and working on the situation given. Hence they will be able to discover the basic principle of the probability, helped by the pictures and written symbols. The arrangement of the textbook where students are exploring the theoretical and empirical probability and then compare both make sure that the 'discovery learning' as Bruner suggested will work well, of course by sufficient help from the teacher [6].

The reason why real-world situations are frequently used is also in correspondence to the explanation of Lesh, Post, and Behr that it is crucial for students to be able to 'model' a situation. Modeling a situation here means translating real-world situation to written symbol [12]. They also explained the essential features of modeling which include: 1) simplifying the original situation by ignoring "irrelevant" (or "less relevant") characteristics in order to focus on other "more relevant" factors; 2) establishing a mapping between the original situation and the "model"; 3 ) investigating the properties of the model in order to generate predictions about the original situation; 4) translating (or mapping) the predictions back into the original situation; and 5) checking to see whether the translated prediction is useful and sensible. By dealing with many real-world situations, students are expected to be able to show the features above so that they will be succeeding in applying the concept of theoretical and empirical probability in the real world since basically probability is a concept that relies on and closely related to real world.

\section{CONCLUSION}

The textbook being studied is the students' mathematics textbook which was published by the Indonesian Ministry of Education and generally used in Indonesia. The probability unit in the textbook is divided into two subunits; 'Understanding Theoretical Probability' and 'Comparing Empirical and Theoretical Probability,' and then closed by 'Competence Test' at the very end of the unit. There are two basic competencies for this unit; (1) finding empirical and theoretical probability from possible output based on a group of data, and (2) experimenting to find empirical probability from real-world problems 
and comparing it with theoretical probability. Since the probability unit is closely related to real-world events; hence, representation in real-world situation form is often encountered compared in this unit, such as in the opening of the unit and the exercises items. The probability unit also uses reasonably many pictorial illustrations of real-world objects, such as coins, dice, spinners, and a menu list. Other than pictorial illustrations, this unit also presents information in tables, arrow diagrams, and a graph. In the unit, written symbols are only encountered three times as a formula of theoretical probability, empirical probability, and expected frequency, and also few times as symbols representing the face of a coin. The using of such variation of representation may help students who have difficulties in translating from realworld situations to written symbols; they may begin by translating from real-world situations to pictures and then translate from pictures to written symbols, and also vice versa.

\section{REFERENCES}

[1] L. Zhe, "Survey of Primary Students' Mathematical Representation Status and Study on the Teaching Model of Mathematical Representation," Journal of Mathematics Education, 5(1), pp. 63-76 2012.

[2] M. Friesen and S. Kuntze, "Pre-service Teachers' Competence of Analysing the Use of Representations in Mathematics Classroom Situation," in Proceeding of the $38^{\text {th }}$ Conference of the International Group for the Psychology of Mathematics Education and the $36^{\text {th }}$ Conference of the North American Chapter of the Psychology of Mathematics Education, vol. 6, 2014

[3] I. Velez and J.P. da Ponte. "Promoting the Understanding of Representations by Third Grade Students," in Proceeding of the $38^{\text {th }}$ Conference of the International Group for the Psychology of Mathematics Education and the $36^{\text {th }}$ Conference of the North American Chapter of the Psychology of Mathematics Education, vol. 6, 2014.

[4] M. Akita and N. Saito. "A Study on Role of Relational Representation on Creativity in Mathematics Education," in Proceeding of the $38^{\text {th }}$ Conference of the International Group for the Psychology of Mathematics Education and the $36^{\text {th }}$ Conference of the North American Chapter of the Psychology of Mathematics Education, vol. 6, 2014.

[5] National Council of Teachers of Mathematics, Principles and Standards for School Mathematics, Key Curriculum Press, Reston, 2000.

[6] S. J. Pape and M.A. Tchoshanov, "The Role of Representation(s) in Developing Mathematical Understanding," Theory into Practice, vol. 40(2), pp. 118-127, 2001.

[7] G. Goldin and N. Shteingold. "Systems of Representations and the Development of Mathematical Concepts," The Roles of Representation in School Mathematics, pp. 1-23, 2001.

[8] M. Sabirin, "Representasi dalam Pembelajaran Matematika," JPM IAIN Antasari, vol. 1(2), pp. 33-44, 2014.

[9] G.A. Goldin, Representation in School Mathematics: "A Unifying Research Perspective," in J. Killpatrick, W.G. Martin, and D. Schifter (Eds.), A Research Companion to Principles and Standards for School Mathematics, 2003, pp. 275-285.

[10] I. Uwingabire and B. Takuya, "Multiple Representations Used by Rwandan Primary Teachers in Mathematics Lessons," in
Proceeding of the $38^{\text {th }}$ Conference of the International Group for the Psychology of Mathematics Education and the $36^{\text {th }}$ Conference of the North American Chapter of the Psychology of Mathematics Education, vol. 6, 2014.

[11] T. Harries and R. Sutherland, The Representation of Mathematical Concepts in Primary Mathematics Textbooks: a Focus on Multiplication (2000), (Online), (https://www.google.co.id/url?sa=t\&rct=j\&q=\&esrc=s\&sour $\mathrm{ce}=$ web $\& \mathrm{~cd}=1 \& \mathrm{cad}=\mathrm{rja} \& u a c t=8 \& \mathrm{ved}=0$ ahUKEwiEu $5 \mathrm{LLhu}$ zVAhVJoJQKHQIPDPAQFggoMAA\&url=http $\% 3 \mathrm{~A} \% 2 \mathrm{~F} \% 2$ Fmath.unipa.it\%2F grim\%2FJharries.PDF\&usg=AFQjCNG A-R3NFuAYtIjFKJCiRbi9bzxIzA), Accessed June $15^{\text {th }}$, 2017.

[12] R. Lesh, T. Post, and M. Behr, "Representations and Translations among Representations in Mathematics Learning and Problem Solving," in C. Janvier, (Ed.), Problems of Representations in the Teaching and Learning of Mathematics, 1987, pp. 33-40.

[13] R. Lesh, M. Landau, and E. Hamilton, "Conceptual Models in Applied Mathematical Problem Solving Research," in R. Lesh \& M. Landau (Eds.), Acquisition of Mathematics Concepts \& Processes, 1983, pp. 263-343.

[14] J. Cai, J.J. Lo, and T. Watanabe, "Intended Treatments of Arithmetic Average in U.S. and Asian School Mathematics Textbooks," School Science and Mathematics, vol. 102(8), pp. 391-404, 2002.

[15] Kementerian Pendidikan dan Kebudayaan Republik Indonesia. Materi Bimbingan Teknis Fasilitator dan Instruktur Kurikulum 2013 Tahun 2017.

[16] Kementerian Pendidikan dan Kebudayaan Republik Indonesia, Matematika SMP/MTs Kelas VIII Semester 2, 2017.

[17] E. M. W. Simatwa, "Piaget's Theory of Intellectual Development and Its Implication for Instructional Management at Pre-Secondary School Level," Educational Research and Review, vol. 5(7), pp. 366-371, 2010.

[18] R. Sutherland, Teaching for Learning Mathematics, Bell \& Bain, Ltd., Glasglow, 2007. 